\title{
CRÓNICA DE LA CHILENIZACIÓN. LA RELIGIOSIDAD ANDINA A TRAVÉS DEL RELATO DEL PADRE JULIO RAMÍREZ ORTIZ. SIERRA DE ARICA, 1922-1931
}

\author{
CHRONICLE OF CHILENIZATION. ANDEAN RELIGIOUSNESS IN THE \\ ACCOUNTS OF FATHER JULIO RAMÍREZ ORTIZ. SIERRA DE ARICA, 1922-1931
}

\author{
Alberto Díaz Araya y Felipe Casanova Rojas ${ }^{2}$
}

\begin{abstract}
El presente artículo analiza dos textos escritos por el capellán militar chileno Julio Ramírez Ortiz (Por la Pampa Adusta y Tierras Grises) que abordan diferentes aspectos sociales de las comunidades andinas de la sierra de Arica durante los primeros años del siglo XX. Estos materiales, elaborados en ocasión del complejo escenario diplomático conocido como chilenización, dan cuenta de una perspectiva sociopolítica y etnocéntrica sobre los indígenas. No obstante, es posible hallar interesantes descripciones etnográficas sobre la organización, práctica y creencias de las comunidades. Dicha ambigüedad, estaría mediada por un pensamiento cronístico de raigambre colonial del autor, el cual busca dar cuenta de la incidencia de las políticas de asimilación cultural desplegadas en la región por el Estado chileno.
\end{abstract}

Palabras claves: Julio Ramírez Ortiz, capellán militar, comunidades andinas, chilenización, etnografía.

This article analyzes two texts written by the Chilean military priest Julio Ramírez Ortiz (Por la Pampa Adusta y Tierras Grises) in which he discusses different social aspects of the Andean communities of Sierra de Arica during the first years of the 20th century. These materials, elaborated on the occasion of the complex diplomatic scenario known as Chilenization, present a complex sociopolitical and ethnocentric perspective on the indigenous peoples. However, it is also possible to find interesting ethnographic descriptions of the organization, practices, and beliefs of the communities. This ambiguity would be mediated by the chronicler's thinking of colonial origin, which seeks to account for the incidence of cultural assimilation policies implemented in the region by the Chilean State.

Key words: Julio Ramírez Ortiz, Andean communities, chilenization, ethnography.

El actual extremo norte de Chile, vinculado al área Centro-Sur Andina, fue anexado al territorio nacional tras la Guerra del Pacífico (1879-1883), siendo una zona que albergaba repertorios culturales y étnicos desconocidos para los oficiales del Estado chileno. Mediante una serie de políticas que buscaron consolidar la soberanía en Arica, los valles y el altiplano, se implementaron acciones para la administración gubernamental y el control de su población, forzando poderosos y -a veces- violentos cambios en las estructuras sociales, económicas y culturales de las comunidades aymaras (Díaz et al. 2010; González 2004).

La presencia del Estado chileno implicó la materialización de una serie de dispositivos cuyo propósito era la circulación de símbolos patrios, modificando las lealtades nacionales para obtener un exitoso resultado en un plebiscito regional que (re) definiría los espacios fronterizos y las identidades en los bordes de la nación (Díaz 2009; Galdames y Díaz 2007). En tal contexto, la sociedad andina se vio incorporada, a través de la administración pública (subdelegaciones rurales, inspectores, retenes fronterizos), la escuela (en la costa y en la sierra) y el reclutamiento militar, al quehacer sociopolítico que las agencias y agentes fueron imponiendo en un contexto denominado como "chilenización" (Díaz 2009; Díaz y Ruz 2009; González 2004).

Dicho sea de paso, también se advierte lo que sucedió con los indígenas que habitaban los poblados precordilleranos, y sus capacidades para articular intereses locales, demostrando creatividad en la

\footnotetext{
${ }^{1}$ Departamento de Ciencias Históricas y Geográficas, Universidad de Tarapacá, Arica, Chile. albertodiaz@uta.cl

2 Programa de Magíster en Historia, Universidad de Tarapacá, Arica, Chile. fcasanovarojas@gmail.com
}

Recibido: marzo 2018. Aceptado: mayo 2019.

http://dx.doi.org/10.4067/S0717-73562019005002101. Publicado en línea: 26-septiembre-2019. 
adopción, acomodación y mediatización con los mecanismos externos impuestos por el centro político (Déloye 2004).

Entre los distintos agentes que el Estado dispuso en el territorio (policías, profesores, subdelegados, inspectores, etc.), se advierte igualmente la presencia de capellanes militares, que gestionaban tanto los sacramentos en las guarniciones, como las tareas pastorales en las antiguas doctrinas coloniales de la sierra ariqueña.

En particular, buscamos aproximarnos al derrotero de los comuneros andinos durante la "chilenización" a través de la obra de un miembro de la Vicaría Castrense, Julio Ramírez Ortiz, arribado a Arica a inicios de la década de 1920. Este sacerdote, siguiendo los patrones evangelizadores de los siglos XVI y XVII, procuró registrar las costumbres de los aymaras, dando cuenta de la introducción de artefactos culturales chilenizadores desplegados por la autoridad para fomentar la nueva identidad nacional (Galdames y Díaz 2007).

$\mathrm{El}$ artículo analiza las observaciones del padre Ramírez sobre los poblados andinos de Guallatire, Pachama, Belén, Putre, Socoroma, Ticnamar, Timalchaca y Codpa, contenidas en dos textos de su autoría: Por la Pampa Adusta, publicado en 1927, y Tierras Grises, divulgado en 1931.

Estos materiales, escritos durante el complejo proceso "chilenizador", evidencian la sensibilidad etnográfica del capellán, quien describió la organización, prácticas culturales, cosmovisión y creencias religiosas de los indígenas, aunque, conjeturamos, dicha agudeza estuvo mediada por un pensamiento cronístico de tipo colonial, prejuicioso y etnocéntrico por lo demás, pues su objetivo no era necesariamente una aproximación guiada por inquietudes culturales. Más bien, provinieron de una búsqueda para la eficacia simbólica del quehacer político-religioso y disciplinador del Estado en la nueva frontera nortina.

\section{Julio Ramírez Ortiz y los Capellanes Militares}

El sacerdote Julio Ramírez Ortiz nació en Santiago en la segunda mitad del siglo XIX ${ }^{1}$. Hijo de Sabina Ortiz Lois y Manuel Ramírez Molina. Luego de su etapa de formación eclesiástica, fue ordenado sacerdote en 1913 (Figueroa 1931:601), asumiendo como Capellán Auxiliar del Ejército en 1920². Junto con su nombramiento, se le asignó el traslado a la Brigada Combinada de Tacna, atendiendo los servicios religiosos de la tropa. Actuó como capellán de la parroquia de Belén, en la sierra ariqueña (Figueroa 1931:601; Ramírez 1927). Tiempo después, fue trasferido a la Marina, instalándose en Arica para desarrollar las tareas de la compañía de "Artillería de Costa" (Figueroa 1931:601). En 1933, fue ascendido a capellán $1^{\circ}$ en la guarnición de Santiago. Tras ocupar la dirección del servicio castrense, se desempeñó en las tareas eclesiásticas de las Escuelas Militares. Finalmente, en 1947, encontrándose en la Comandancia de Guarnición de Santiago, se le concedió el retiro ${ }^{3}$.

Durante su estadía en Tacna y Arica, asumió la elaboración de los discursos para las conferencias patrióticas, los aniversarios del combate naval de Iquique (21 de mayo) y la toma del morro de Arica (7 de junio), como también las homilías del ceremonial litúrgico ${ }^{4}$. Todo, en paralelo con su interés por la literatura y el folklore ${ }^{5}$.

Consignemos que a inicios del siglo XX, el conflicto diplomático entre Chile y Perú no solo generó tensiones entre políticos y negociadores de ambas naciones; trajo consigo una serie de disputas por el control eclesiástico de la zona. Sabemos que la curia de Tacna y Arica siguió dependiendo del Obispado de Arequipa, y que al estar conformada por sacerdotes peruanos, fue acusada por la autoridad chilena de ejercer una fuerte influencia nacionalista, difundiendo discursos patrióticos en contextos litúrgicos, y llamando a la población a votar a favor del Perú en un hipotético plebiscito (Palacios 1974; Choque 2013). Dicha propaganda tensionó las relaciones entre la curia chilena, la peruana y la feligresía local. Así las cosas, el conflicto llegó a un punto de inflexión cuando la autoridad chilena decretó, en noviembre de 1909, la clausura de las parroquias y templos peruanos, disponiendo la expulsión, en marzo de 1910, de los clérigos de dicha nacionalidad. En síntesis, dejaron de funcionar todos los servicios eclesiásticos en Tarata, Sama, Putre, Codpa, Belén, Estique y otras localidades.

Con el apoyo del Vaticano, a través del Breve Pontificio In bac beatissimi Petri Cathedra del 3 de mayo de 1910, el Estado chileno trasladó a un conjunto de capellanes militares a las provincias del norte, agrupándolos en la Vicaría General Castrense, que operaba independiente del resto de los obispados chilenos (Precht 2005; Fierro 2010). Dentro de sus atribuciones, la curia castrense asumió los servicios religiosos, y de igual manera, la introducción de la retórica patriótica en sus tareas eclesiásticas y con un claro perfil militar en el quehacer pastoral.

Recorriendo los poblados serranos y el altiplano de Arica, según la programación del calendario católico, los capellanes llevaron a cabo tareas en festividades patronales y en la administración de los sacramentos, ocupándose de parroquias y capillas, de la enseñanza de la catequesis en las escuelas chilenas ${ }^{6} \mathrm{o}$ como profesores de moral en las cárceles ${ }^{7}$.

De esta forma, Eduardo Oyarzún Miller asumió la capellanía de Putre ${ }^{8}$; Arturo González la parroquia de Codpa ${ }^{9}$ y el citado Julio Ramírez, el poblado de Belén ${ }^{10}$. Asimismo, Luis Arturo Moraga estuvo a cargo de la 
festividad de la Virgen del Rosario de las Peñas en $1922^{11}$ y Benjamín Flores realizó "algunos servicios relijiosos" en el poblado de Poconchile en el valle de Lluta ${ }^{12}$.

En otra faceta, la predisposición de Julio Ramírez por la oratoria y los discursos públicos provino de su permanente interés por la creación literaria. Sabemos que fue distinguido con la Bendición Apostólica del Papa Pio XI, por su trabajo en las obras "El Curso Superior de Historia Bíblica" y "El Cuaderno de la Doctrina Cristiana en Ejemplos". No obstante, su producción no solo se limitaba a una creación sojuzgada al espacio doctrinal ${ }^{13}$.

Durante su estancia en Arica, fortaleció sus cualidades de escritor, dedicando parte de su tiempo a la descripción de costumbres y del folklore local, que serían publicadas en dos textos: "Por la Pampa Adusta" y "Tierras Grises". A primera vista, pareciera que Ramírez describe las aldeas serranas como partes de un viaje en común. Sin embargo, agrupa diferentes materiales que dan cuenta de variados momentos y recorridos por la precordillera y altiplano, en ocasión de alguna fiesta patronal, asistencia a santuarios o actividades pastorales.

El primer texto, "Por la Pampa Adusta", está redactado en base al trabajo parroquial que desarrolló por "más de seis meses" en Belén y Guallatire (Ramírez 1927:8), durante, creemos, el año 1922. En su segunda obra, "Tierras Grises", describe la actividad pastoral en las comunidades de Putre, Socoroma, Ticnamar y Codpa. En esta, reconoce que viajó al primer poblado "en pleno Agosto" (para la fiesta de la virgen de la "Asunta") con tres indígenas (Ramírez 1931:15). De allí, continuó a Socoroma, señalando que "el camino (...) es espléndido; sube primero en zig-zag sin violencia, y desde arriba el panorama se va dilatando y embelleciendo, y los potreros convirtiéndose en vergeles y el pueblucho de Putre, transformándose en una nívea aldea de idilio" (Ramírez 1931:37). No obstante, la travesía a Ticnamar no habría formado parte de este itinerario. No existe referencia a una ruta seguida desde Socoroma. La descripción del viaje refuerza la presunción que partió de Belén, lugar donde desarrolló una tarea como párroco. Invitado por el subdelegado para que asistiese a la fiesta del Tránsito de la Virgen, celebrada en la quincena de agosto, pasó por Yactire, Tojotojone y Lupica; ubicados en el camino hacia Ticnamar (Figura 1). Sobre Codpa, tenemos certeza de que se trató de un periplo distinto a los ya identificados, pues formó parte de la Visita que el Vicario General Castrense Rafael Edwards realizó a algunas aldeas durante los últimos días de mayo de $1923^{14}$.

Un abordaje analítico de sus escritos permite incluir a Ramírez dentro del grupo de precursores del conocimiento etnográfico de las comunidades andinas del norte chileno (Gundermann y González 2009).
Viajaba con un diario de campo, en el que registró "los apuntes principales" de su paso "por la sierra y por la pampa ariqueña" (Ramírez 1927:6). Se autodenominaba como "capellán cronista", estableciendo una relación de oficio directa con los misioneros del período colonial. En cada aldea, caserío o poblado, se acompañó de informantes, como Filiberto Ochoa de Putre o Juan de Peña, quien lo guió en su camino a Ticnamar. Además, aprendió nociones de la lengua aymara, recomendando "a los que se internan por la sierra con misión especial, a los sacerdotes, capellanes, a las autoridades, no se vayan ayunos del idioma, siquiera pronuncien las frases más usuales, tómense el trabajo de estudiar las raíces" para comprender "con mejor claridad, la sicología de la raza" (Ramírez 1927:116).

De igual manera, poseía un interés por realizar un trabajo de campo mediante lo que la etnografía ha denominado "observación participante" (Guber 2001), justiciando con información y datos diversos los objetivos que demandaban la publicación de un repertorio de costumbres, cosmovisiones y prácticas rituales y festivas indígenas.

No obstante, Ramírez condiciona gran parte de estas observaciones mediante el propósito que guía su labor etnográfica: comprobar el "estado de avance" de las políticas chilenizadoras en el área andina. Para ello, se sirvió de los apuntes sobre sus estadías en las antiguas doctrinas coloniales para concebir in situ un conocimiento que permitiese comprobar las transformaciones de las tradiciones locales. Así, "las ceremonias indígenas citadas y los hábitos religiosos y sociales" narrados en sus textos "han sido observados de visu por el capellán cronista, que no tiene otra pretensión que dar a conocer un nuevo aspecto de la obra realizada por el Gobierno de Chile en estas regiones lejanas y desconocidas", destacando "la labor silenciosa y oscura de los capellanes castrenses, enviados a laborar por Dios y por la patria en esta tierra estéril" (Ramírez 1927:6). Bajo estos parámetros, podemos mencionar una asamblea patriótica organizada por Ramírez en el valle de Azapa en 1925, en la cual, junto a otros sacerdotes chilenos, expusieron sobre los progresos verificados en los valles durante la administración chilena, mencionando la creación de escuelas, caminos, telégrafos, sistemas de regadío, entre otros, como parte de la propaganda nacionalista ${ }^{15}$.

\section{La Crónica y la Extirpación}

Julio Ramírez apuntó en sus textos una serie de prejuicios respecto de las costumbres de los aymaras. Vinculando una tradición cronística con una perspectiva etnográfica que mediatizaba el conocimiento del "otro", culturalmente desconocido (Pérez 2008) -en este caso, los indígenas-, Ramírez reprodujo una imagen evolutiva 


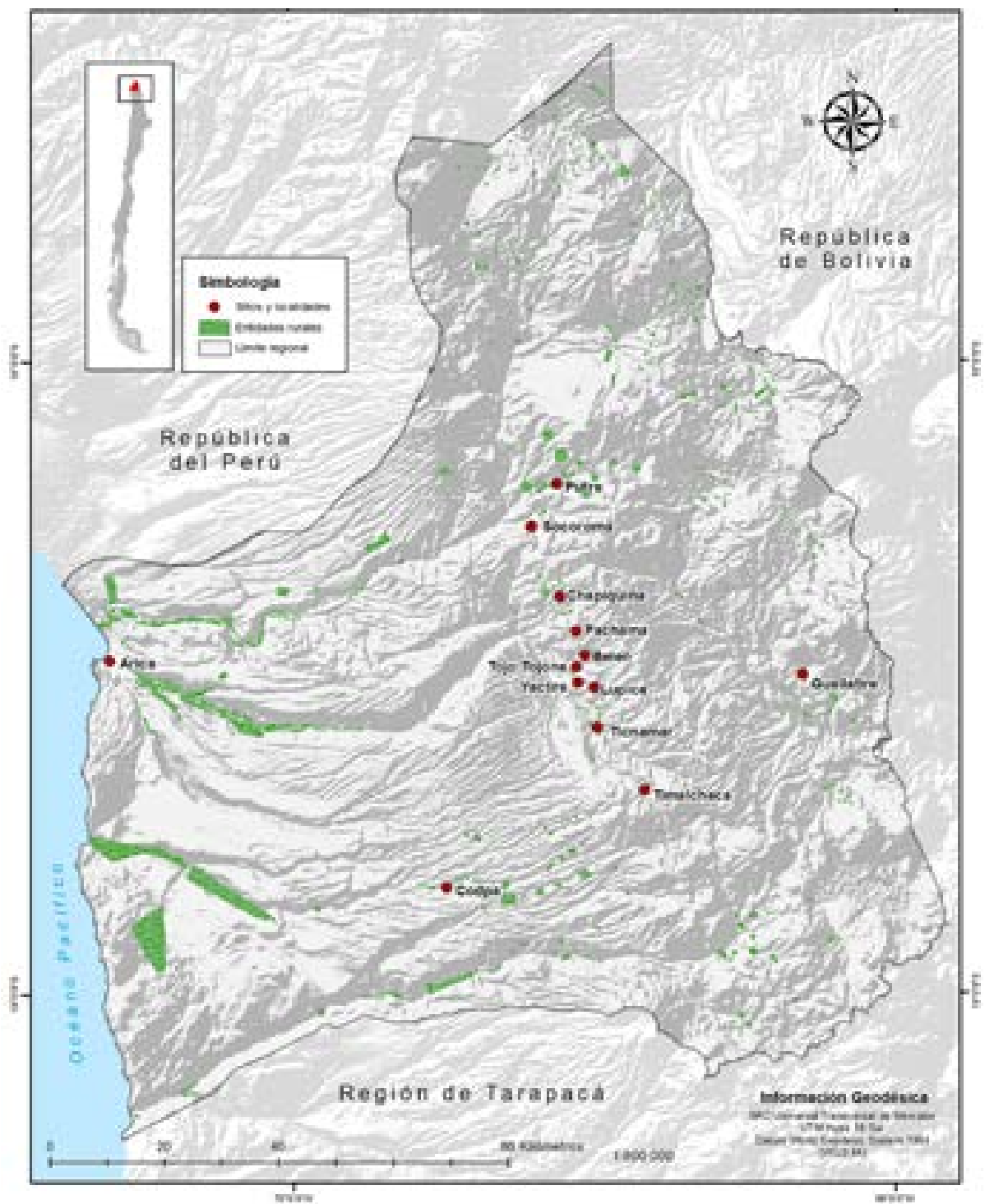

Figura 1. Sitios y localidades visitados por el capellán Julio Ramírez Ortiz. Mapa: Lic. Paulina Ponce Philimon.

Sites and localities visited by chaplain Julio Ramírez. Map: Lic. Paulina Ponce Philimon.

de "lo primitivo" hacia "lo civilizado" durante la chilenización (Solodkow 2010).

Estos enfoques, nos permiten ligar los preceptos del clérigo con el proyecto evangelizador colonial del padre Joseph de Acosta (1590), a quien admiraba Ramírez en su rol de cronista, según la visión del sujeto andino y los métodos utilizados para su observación.

De hecho, el capellán reconocía "la riqueza y antigüedad" del idioma aymara para instruir los "hábitos morales" entre los comuneros. La inclusión del estudio idiomático y aprendizaje de la lengua de los indígenas se fundaba en la necesidad de difundir el catecismo entre la población en su idioma (Mattei y Casalini 2015), en concordancia con las disposiciones entregada por el Segundo Concilio Limense (1565), que intentó contextualizar los dogmas del Concilio de Trento (1564) a la realidad del Perú, exhortando a los curas doctrineros a emprender procesos catequéticos 
en lengua aymara o quechua (Díaz et al. 2012). En los materiales de Ramírez, se muestra en abundancia una predilección por el idioma aymara que se hablaba en los poblados andinos del interior de Arica, puesto que, basado en sus lecturas de "etnólogos", "lingüistas" y "filólogos"16, lo consideraba "uno de los idiomas más antiguos y nobles de América" (Ramírez 1927:109).

Atento a los postulados del "americanista Acosta" -como lo denominó-, Ramírez estudió el aymara, arguyendo que "los nombres aplicados a las cosas de uso familiar y a los animales tienen sonidos guturales y cacofónicos que guardan íntima relación con la naturaleza del objeto o del animal nombrado", y que "los nombres que se han aplicado a las montañas, a los ríos, a los volcanes, en general, casi todos los nombres geográficos" tenían una raíz y significado en dicha lengua (Ramírez 1927:110-111). Este afán por superar barreras idiomáticas como insumo para solventar el trabajo catequético y evangelizador, pareciera que también se orientó en el inicio de una campaña para erradicar las "supersticiones" que mantenía la feligresía. En Tierras Grises, Ramírez señala que:

Los capellanes han comprendido que es deber de ellos elevarles el concepto religioso [a los indígenas] y extirpar los errores y supersticiones que afean la doctrina de Jesucristo que profesan. Les han enseñado que el culto que el cristiano ofrece a las imágenes, que la oración que los labios profieren, no se detiene en esas imágenes, en la madera o en el yeso o en la piedra, sino que sube hasta el trono donde el santo mora (Ramírez 1931:31) el destacado es nuestro.

Sin duda, el capellán no consentía una religiosidad distinta a la practicada en el campo o alrededores de Santiago. Por ello, se interesó por describir las fiestas, ceremonias y sistema de cargos religiosos desconocidos para él. Así, por ejemplo, cuando asistió a la festividad de la Asunción de la Virgen de Ticnamar, frente a los peregrinos marchando con caballos y burros cargados con pan, charqui, queso, carbón y otros enseres, llevó a preguntarse "¿por qué en la mente del indígena van inseparables las dos ideas: el jolgorio y la solemnidad religiosa, el alcohol y el incienso?" (Ramírez 1931:50).

Consiguientemente, destacó los cargos comunitarios. En su obra, identifica a dos figuras relevantes que formaban parte del sistema de congregación ceremonial andino: el mayordomo y el alférez (Díaz et al. 2014; Ruz et al. 2011). El primero, encargado de custodiar los bienes del templo y la imaginería religiosa; recibir y despedir a las compañías de bailes y músicos, "vestir" al Santo y mantener velas encendidas durante la celebración (Ruz et al. 2011;
Díaz et al. 2014), es descrito por Ramírez al señalar que el mayordomo:

Durante dos años se compromete un vecino a cuidar del servicio del culto. Tiene el título de mayordomo, guarda los ornamentos, toca las campanas, en una palabra, sirve de sacristán mayor; en cambio, tiene todos los honores y prerrogativas de su cargo y campo de siembra para ayudarse (Ramírez 1927:13) el destacado es nuestro.

Sobre el alférez, decía que asumía las funciones festivas, y que "de su cuenta corría la alimentación y la bebida de las gentes, y más que todo, de los musicantes, terriblemente sufridos por ingerir alcohol y caldear la garganta en la helada noche" (Ramírez 1931:73). Ciertamente, el alférez concentró especial interés en el clérigo. Siendo un cargo comunitario que no escatimaba recursos para la celebración del patrono del pueblo, asumiendo costos operativos relativos a la celebración, era quien disponía de los medios para la fiesta, la asistencia de los fieles y la manutención y pago del sacerdote (Díaz et al. 2014).

Las referencias anteriores ilustran formas de organización y celebración novedosas para el capellán; instancias donde se observa el despliegue de una feligresía que asumía roles de profunda raigambre cultural, pues la ausencia de sacerdotes desde la época colonial, propiciaron el surgimiento y posicionamiento de los cargos religiosos (mayordomos y alférez) como articuladores de una religiosidad andina, sin la atención permanente de misioneros, y con claros elementos de prestigio y poder comunitario. En tal sentido, los cargos y las imágenes de los santos patronos o vírgenes en las fiestas patronales, Corpus Christi o Cruces de Mayo, constituían soportes para los repertorios y significados culturales propios de la feligresía indígena (Díaz et al. 2014), amén de una relación histórica entre la liturgia católica y la eficacia simbólico-ritual de la figura del Santo Patrono, la Virgen, el Señor o la Cruz más allá de la cuadrícula del dogma católico. Las manifestaciones en torno a las imágenes son descritas por Ramírez:

Los vecinos han llevado a la iglesia las imágenes familiares que guardan en sus casas, santos de todos tamaños, el san Jerónimo de hermosa barba florida, la Virgen de Mercedes, la Virgen del Carmen, el Niño, San Antonio, etc., etc. Las repisas y nichos se pueblan de imágenes, algunas de una fealdad suprema el destacado es nuestro. Estos artistas primitivos que han pasado por estos pueblos de la sierra, se complacían en revestir a sus imágenes de un aire ceñudo y terrible, ponían en los ojos una hosca severidad y alargaban las narices o las aplastaban con 
crueldad extraña. Hay venerables apóstoles, confesores que inspiran terror y sin embargo, los devotos los miran con ternura sin ejemplo. Aquellas imágenes que han visto al hacer, que han presidido los grandes días, siendo testigos de tantas lágrimas, llegan a formar parte de su familia; de aquí que en mucha de esta la imagen misma cobra una importancia capital y ella reciba el homenaje cotidiano de oraciones y de luminarias (Ramírez 1927:23) el destacado es nuestro.

Consta que estas descripciones contienen implícitas intenciones. La concepción de las imágenes andinas acarreó tensiones entre los capellanes y los comuneros serranos. Los sacerdotes concebían una piedad religiosa que distaba de la figura del Santo Patrono en contextos ceremoniales andinos, desconociendo las funcionalidades y significaciones que tenían dentro del entramado religioso aymara (Díaz y Lanas 2015; Díaz y Málaga 2013). De hecho, Ramírez consigna la redefinición de las acepciones religiosas de los indígenas, junto con la resistencia comunitaria. En efecto, señala que:

Las antiguas imágenes, que ponían miedo en el corazón con sus caras foscas y sus barbas revueltas, han sido trocadas por los capellanes y gracia a la munificencia del Obispo, por bellísimas imágenes moderna que elevan el ánimo.

Hace luengos años, un capellán quiso introducir algunas reformas en las fisonomías de ciertas beneméritas imágenes, un San Jerónimo ceñudo $\mathrm{y}$ un San Miguel de enorme casco, y hubo una escandalera y vocería que, por nada, arde Troya y sale encumbrado el Tata (Ramírez 1931:31) el destacado es nuestro.

En concordancia a su investidura, el clérigo critica la "embriaguez general" de los indígenas durante las festividades (Ramírez 1027:18). En ocasión de su visita a Ticnamar, fue informado que el mayordomo "está con el alma ausente, pues ha bebido desde hace dos días; lo mismo que pasa con el ayudante y con sus respectivos consortes". Utilizando un tono sarcástico, refería a los pobladores andinos como aquel que "conserva con amor las tradiciones", ya que "hace más de cincuenta años le aconteció lo mismo al Prelado de Arequipa que visitaba a su grey" durante la fiesta (Ramírez 1931:66). Desde otra perspectiva, la fiesta patronal, junto a otras manifestaciones, fueron asimismo observadas por distintos agentes chilenos desde la dicotomía civilización/ barbarie, introduciendo dichos componentes a sus registros. En 1927, un oficial militar solicitó suspender una fiesta en Azapa, usando los siguientes adjetivos:

Este comando, ha podido imponerse, que con el pretexto de conmemorar fechas y homenajes a tal o cual santo una muchedumbre harapienta y digna de verdadera lástima, se entrega en forma desenfrenada a remoliendas que están en absoluto reñidas con la cultura de un pueblo, cuyas autoridades y elementos representativos tratan a toda costa de levantar. En estas fiestas, no toman parte los elementos nacionales, pues con rarísimas escepciones, son los peruanos y bolivianos los que lo llevan a la práctica. No vaciló (...) en calificar de retroceso a la civilización, y pernicioso ejemplo el que continúe verificándose tales fiestas y considero un deber primordial hacer cesar este estado de $\underline{\operatorname{cosas}}^{17}$ el destacado es nuestro.

Como se advierte, existe una diferencia entre "lo chileno" y lo tradicional que representaba a lo "peruano", "boliviano" e indígena. Los funcionarios gubernamentales exponen un contrapunto entre el Chile aparentemente moderno y civilizado y una comunidad local alterizada y exotizada a partir del otorgamiento de atributos negativos, bárbaros y tradicionales (Ruz et al. 2017).

\section{Etnografías en la obra de Julio Ramírez}

Los textos de Julio Ramírez poseen cierta sensibilidad etnográfica que, en grandes pasajes de sus escritos, distinguen un interés por retratar la ritualidad aymara. Con dedicación, prestó cuidado y atención a los ritos de la Vilancha y el Pachallampe.

Sobre la Vilancha, Ramírez señala que "apenas se usa y muy ocultamente en los pueblos más indígenas y ocultos de la tierra", pues constituye parte de las "costumbres idólatras, inmemoriales, de los indios" (Ramírez 1931:64). En cuanto al rito, señala que:

El que preside degüella a la víctima, la llama, la alpaca o el cordero expiatorios, y con destreza le arranca el corazón y va rociando con la sangre caliente la tierra, los muros adyacentes al lugar en donde se ha verificado el sacrificio (...), sangre derramada en expiación de crímenes, purificación del ambiente por medio de la efusión de la sangre de un animal (Ramírez 1931:64) el destacado es nuestro.

De acuerdo con sus informantes, el rito era "una costumbre muy añeja", por cuanto "la tierra tiene también hambre y sed y se enoja con los crímenes de los hombres" (Ramírez 1931:64). Con esta respuesta, se visualiza el rol y significado que tienen los ritos asociados a la tierra en la cosmovisión andina, donde la tierra debe recibir sacrificios. La Vilancha, así entendida, constituye un "pago" que posibilita la reciprocidad, continuidad y subsistencia de la comunidad aymara que mantiene sus vínculos con la pachamama y con las 
deidades tutelares, apus y mallkus que habitan en los cerros protectores, entre apachetas y cruces, siendo una costumbre aún practicada en la sierra ariqueña (Choque y Díaz 2017).

En cuanto a los artefactos ceremoniales, detalla la inclusión del alcohol y la hoja de coca en la mesa ritual, enfatizando la prohibición de su uso decretada por las autoridades chilenas y las formas de internalización ilegal desde Bolivia practicadas por los comuneros. En efecto, señala que -para 1927- la coca "está prohibida", pero que "suele pasar, de tarde en tarde y de contrabando" por los retenes fronterizos. En cuanto al alcohol, agrega que "tiene encima todas las penas de la ley", y que "jamás se ve ahora esa larga caravana de llamas, que llevaban los tarros de veneno para acabar con la abandonada raza" durante las fiestas (Ramírez 1927:87); prohibiciones que emanan desde la autoridad coercitiva.

El pachallampe, consiste en una ceremonia comunitaria en torno a la siembra de la papa que incluye la participación de los mayordomos y las imágenes de los santos patronos, acompañados de cánticos, instrumentos musicales y danzas (Choque y Díaz 2017). En Belén, el capellán observó dicha ceremonia, a la que dedicó varios párrafos, definiéndola como una actividad en la que los indígenas ayudaban "al mayordomo de la iglesia en las siembras que hace en el terreno que la comunidad le da, para que haga los gastos del culto". En el ritual, los pobladores de Belén dispusieron un terreno en la parcela "El Romeral, que distaba "sus quince cuadras del pueblo", para llevar a cabo el rito.

Durante la víspera, los mayordomos regaban la tierra para la próxima jornada. Una vez llegado el día, la siembra se llevaba a cabo:

Por la mañana sale entre retumbos de camaretas y cohetes, la alegre comparsa de mozallones y garridos donceles en sus enflorados, llevando en árguenas y ancaches la semilla de papas o habas que van a sembrar. Van ellos también, como sus grises y pacientes rucios, con flores en los sombreros o con festivos trajes de Carnaval; es un desfile pintoresco celebrado con gran vocería y carcajadas por los pobladores, mientras recorren todas las calles en ese dulce trotecito asnal hasta desembocar al campo, ya dorado por ese otoño sui generis de la sierra (Ramírez 1927:132).

Luego del almuerzo, los comuneros se trasladaban al sitio del sembrado. Allí, las mujeres "belenitas están trajeados con sus atavíos de lujo y las matronas y doncellas llevan a cuestas sus lligllas multicolores", llevando "en pequeñas andas al Niño Dios en una urna de cristal", envuelto "con un poncho de vicuña y con chalina gris, para que el aire helado no le hiera sus delicados miembros". En el lugar elegido:

... el galán labrador, en mangas de camisa, elige una guayna o huaña, de compañera, que lleva en un saquillo o atado las semillas que él va a arrojar al surco ya abierto. Están las damas coronadas de flores, así como los varones, y todas ellas, bajo la mirada materna, esperando al que las va a elegir de compañera. Él se acerca, ella acepta sonriente y le coloca el obsequio, algún lazo de seda, algún ramillete oloroso o un billetito azul o joya de similor o el modesto papel con que la puede adquirir. Diez a quince parejas van recorriendo los surcos con gran algazara, sudando y riendo el varón el ahondar el surco, y ella, con melindres, echando la semilla. Todo esto bajo la mirada vigilante del Mayordomo, que es dueño de casa, y de sus esposas que vigilan el lunch y el vino para cuando la fiesta termine (Ramírez 1927:134).

Luego, apunta que:

La siembra ha durado unas dos horas; la morena tierra ha cubierto de nuevo el surco y las parejas coronadas de nuevo con flores frescas, fragantes flores campesinas, cogidas allí mismo, conversan y se aprestan para la danza del ceremonial. Las guitarras, manejadas por los maestros Choque y Zegarra, el bajo con carraspera y el tenor abaritonado, dan los primeros compases. (...) Volvemos atrás y hallamos la fiesta que se arde. Se ha formado una ronda y los mozos y mozas, graves varones y solemnes y robustas matronas, tomados de la mano, como colegiales, van danzando en torno de los músicos cantores y saltando con extraña agilidad (Ramírez 1927:134).

La danza ceremonial es descrita como "lenta", siendo armonizada por la entonación de diversos cantos y coplas. Ramírez detalla la composición letrada de la música, preocupándose por apuntar su verbalización en español y aymara:

\section{Pachayampe/iOuilaqui Yampe!/Quimsa Rosas/ Tay Pillampe. \\ (...) \\ Situhuay/Saraquituversull/Versullñaipiftioukama (Ramírez 1927:134).}

La performance ritual que Ramírez describe in extenso, permite reconocer el valor del registro etnográfico y el esfuerzo por relevar detalles de los 
diferentes actores que movilizan los actos y momentos ceremoniales que el pachallampe posee. La profusa indagación sobre el rito de la siembra de la papa, la disposición de los cuerpos, las vestimentas de mayordomos, imágenes de santos y vírgenes, los detalles de los ropajes de las mujeres y hombres, con sombreros ataviados con flores y llijllas multicolores, permiten seguir la escena con los versos de los guitarreros y cantores, que entre coplas armonizan el despliegue en las chacras, con la repetición del coro de danzantes, tal como se realiza en comunidades serranas de Belén, Pachama, Socoroma o Putre (Choque y Díaz 2017). Debemos consignar que las descripciones que realiza el padre Ramírez son mucho más extensas, e incorpora detalles valiosos en su narrativa etnográfica; nosotros solo reproducimos fragmentos que subrayan las ideas de fondo que problematizamos sobre la religiosidad y el paisaje sonoro andino.

Volviendo al rito, Ramírez añade que una vez concluida la siembra, los indígenas realizaban una fiesta en la localidad, con bailes, música y bebían pintatane (Ramírez 1927:138). El pintatane es un vino dulce preparado en el valle de Codpa y es de consumo ritual y festivo en los poblados precordilleranos.

Sobre la música, explica que en las fiestas participaban músicos de lacas y tambores. Sobre las comparsas de laquitas, agrega:

Estos laquitas... que tan importante papel desempeñan en las festividades religiosas de los pueblos (...) Hacen sus ensayos con muchos meses de anticipación a la fiesta, en algún galpón olvidado; se traen una imagen de María, le colocan sus velas y ante ella entonan sus cantares con el desentono y los gritos que el caporal les tolera (...) Aunque el moreno o laquita o musicante de la sierra no tiene la riqueza de atavíos de sus antecesores, lleva sus faldellines de terciopelo y sus chuspas con bordados de plata y gorros florentinos con plumajes y airones dignos de figurar en el tocado de una elegante de pueblo y los más desengañados de semblante usan sus máscaras de carnaval (Ramírez 1927:140).

Las lacas o lakas son aerófonos de filo, sin canal de insuflación, conocidas tradicionalmente por su expresión latina (zampoña), que han formado parte del ceremonial sonoro e instrumental del mundo andino desde tiempos precolombinos (Chacama y Díaz 2011), participando en recepciones, fiestas patronales, días de difuntos y otras actividades comunitarias (Díaz 2009).

En otro momento, en Guallatire, la comunidad recibió a Julio Ramírez con "una banda de pitos y quenas", que "arranca sus tristes melodías al primitivo instrumento" acompañado por "un viejo bombo" que "marca con furia los compases". Se intriga por la sonoridad de las quenas, ya que sobre este aerófono escuchó de sus informantes "que algunas quenas son fabricadas con huesos de difuntos, por eso tienen esa melodía soñolienta y trágica que penetra hasta los tuétanos" (Ramírez 1927:176). Pero, como era de suponer, dichas festividades se veían influenciadas por las acciones del Estado, en un contexto aculturador que en los segmentos indígenas veía elementos de peruanidad que era imperioso revertir (Díaz et al. 2013). De hecho, es el mismo capellán que distingue este fenómeno cuando una banda de músicos del pueblo de Belén, le brinda una serenata en la que se interpreta el himno nacional chileno (Ramírez 1927:19).

Como parte de las sonoridades del mundo andino, las manifestaciones incluían un amplio repertorio de musicalizaciones y bailes (huaynos, cacharpayas, morenos, entre otros.).

Entre otras ceremonias, destaca la descripción del pisa - pisa, desarrollado durante la vendimia en Codpa. Ramírez tuvo ocasión de observar la cosecha de la uva y la preparación del vino:

La aldea está enfiestada: de todas las casuchas y mansiones brotan canciones jocundas y van por los caminos los vendimiadores con un aire tal, que alegra hasta la misma cenicientas pampa... En los pacientes borriquillos acarrean la uva hacia el corral de la casa. Cada propietario tiene su viñita que acaricia y mima como a la niña de sus ojos (Ramírez 1931:130).

Cuando la extensión de la chacra era muy grande, "viene a prestar auxilio al dichoso propietario gente de otros poblachos, pues hay allí mesa puesta, algún llama lechón o un par de corderos gordos que refocilarán como primera recompensa a los vendimiadores" (Ramírez 1931:130). El proceso de elaboración del vino codpeño requería "bandear la uva" (colocar la fruta sobre alfombras y tapices para asolearla). En seguida, "los vendimiadores, desnudos de pie y pierna comienzan la danza sobre el tapiz de la uva madura", cantando la siguiente letra:
Pisa, pisa, compañero,
Pisa, pisa con valor, sacaremos vino rico de la viña del Señor (Ramírez 1931:131).

Una festividad igualmente importante era el Carnaval. Para Ramírez, era "la fiesta pagana exultante que cuenta con sus furibundos cultores", pues la comunidad invertía sus roles y desplegaba prácticas expresivas que incluían trajes, danza, música y agua. En efecto, en Codpa "los sesudos varones adormilados, que pitaban sus cigarrillo de hoja a la sombra del pegujal de la mansión, y las 
matronas ilustres (...), se transforman, y como vivarachos mozalbetes, sienten el cosquilleo" carnavalesco, exhibiendo "disfraces y colorines", danzando, gritando y formando "coros al compás de la zampoña pastoril". El ritual incluía "armarse de jeringas y bombines (...), mangueras y de baldes (...), para descargar el chubasco sobre el paseante descuidado o la viejecilla que chancletea" (Ramírez 1931:134). En definitiva, la fiesta patronal, la vendimia o el Carnaval constituían expresiones culturales y modelos comunitarios de interacción que permitían, año a año, "pasar la fiesta".

La riqueza de las observaciones del capellán, las contrasta con la información de las "viejas y polvorientas crónicas". Con todo, las descripciones sobre las ceremonias y sonoridades andinas tienen, conjeturamos, un origen en la labor cronística del "maestro Gil González y Dávila". Así, en Por la Pampa Adusta, Ramírez puntualiza que el mismo procedimiento fue realizado por el cronista, quien dio cuenta de "los danzantes y músicos indios (...) vestidos a la usanza antigua española" en una ceremonia indígena del siglo XVI (Ramírez 1927:37). Empero, el ejercicio de Ramírez no estuvo totalmente circunscrito a la sensibilidad etnográfica sobre prácticas ceremoniales, dancísticas o instrumentos musicales; pues, el relato cronístico tuvo al unísono, una aplicación sujeta a dar cuenta de la efectividad de la chilenización en la sierra de Arica.

\section{Crónica de la Chilenización}

En ocasión del inicio de la fiesta de San Santiago de Belén, un grupo de comuneros llegó hasta la casa que ocupaba Julio Ramírez para "dar la serenata a la puerta con frenético entusiasmo", entonando "la Canción Nacional" (Ramírez 1927:18).

Sabemos que la utilización de diversos dispositivos, como los himnos, para la propagación del sentimiento nacional chileno en la población andina y peruana en las provincias de Tacna y Tarapacá, abarcó gran parte del quehacer cotidiano de los habitantes (Díaz 2006, 2009).

En la obra del sacerdote se advierte algunas formas en que operan los dispositivos chilenizadores y componentes xenófobos al interactuar con los comuneros. Durante la fiesta de San Santiago de Belén, para la "corrida de gallos" se refiere a un boliviano que participaba en el juego como "moreno subido, caballero en un pingo zaino, flaco como esqueleto", del cual "podía decirse lo de la copla: "era negro el corcel, negro el arreo, negra también las relucientes armas' y para completar su negrura fué también negra su suerte, pues aquel proyecto de animal tropezó en un terrón y tiró al desdichado por las orejas, por suerte sin romperle ningún hueso" (Ramírez 1927:29). También estaba un "carabinero de talla gigantesca"; "hermoso prototipo de la raza araucana" que "parecía un príncipe ante los monigotes que [le] habían disputado el triunfo" (Ramírez 1927:29-30).

En otros párrafos, destaca la "obra que Chile ha realizado, en menos de cincuenta años, en toda la región norte hasta el límite del Altiplano" (Ramírez 1927:190). En la "obra civilizadora", el trabajo de los capellanes "sobre el alma indígena" como una labor de formación espiritual y ciudadana, marcando un punto de inflexión entre las viejas costumbres y "los hábitos de honradez y piedad cristiana" (Ramírez 1931:23). El capellán "les hablaba de la Patria y despertaba en sus oscuras almas esos relámpagos de amor y reconocimiento que les hacían estallar en himnos de júbilo" (Ramírez 1927:191). A su vez, la obra era sinónimo de progreso moral:

La juventud [indígena] que es la flor de un pueblo, ha respondido al llamado de su jefe espiritual: los huraños jovenzuelos de antaño, las zagalejas que andaban por los breñales, a salto de mata, llevando al desgaire la revuelta cabellera y huyendo del agua fría como del mismo demonio, ahora, dejaba la bayeta en el fondo de la cajuela y del arcón, y limpias y peinadas, han tomado la vigüela o el mandolino para concertar los sones y dar serenatas y lucir las dotes musicales en fiestas patrióticas y religiosas; y los desaliñados galanes, emponchados, que ocultaban su mirar bajo la negra maraña del pelo crecido, ya van muy pintiparados y aliñados y usan traje de paño y sombrero de paja, y al cuello un pañuelito remolón (Ramírez 1931:23) el destacado es nuestro.

En cuanto a la escuela chilenizadora se refiere como "la marca de fábrica", consideradas "faros de luz [que] luchan con las tinieblas y convencen a los viejos recelosos de la importancia y de la necesidad de la instrucción" (Ramírez 1927:192). En Socoroma, dice que la profesora "ha sabido comprender en toda su belleza el apostolado de la educación y no se contenta con cumplir puntualmente sus pesadas labores, sino que educa, forma los corazones y las almas y les infiltra [a los estudiantes aymaras] con paciencia las virtudes cristianas y el patriotismo y la honradez y la laboriosidad"(Ramírez 1931:38). Desde unaperspectiva etnocéntrica, enfatiza la eficacia del dispositivo chileno en la erradicación de ciertas costumbres andinas.

Aparte del sistema escolar, el reclutamiento militar constituyó una herramienta de significación para el refuerzo del vínculo con la nación (Anderson 1993; Bourdieu 1986; Díaz 2009). Ramírez lo concebía como "el complemento de la educación cívica del individuo", y enfatiza:

El servicio militar obligatorio es una escuela cívica y de civilización integral, insustituible; 
junto con la instrucción que la Escuela proporciona gratuitamente en todos los poblachos y caseríos, contribuye eficazmente a formar hombres útiles para la sociedad, que de otra manera habrían vegetado como parásitos, adheridos a la gleba, como aquellos tristes campesinos semi-salvajes (Ramírez 1927:98).

Para demostrar su afirmación, recurrió al caso del comunero Recaredo Andía, a quien se refería como "un indiecillo hirsuto que medraba apenas el sustento cultivando una parcela miserable de sus mayores". El hombre "tenía el aspecto sumiso y encogido de los aymaráes"; aunque, sabemos, "fué al cuartel del [regimiento] O’Higgins, cuando la hora llegó, y al año la transformación estaba hecha". El Ejército "devolvía a la sociedad otro hombre en lugar del guiñapo humano que había recibido", pues "Recaredo era ahora un mozallón cobrizo, de ancho tórax, con hábitos de cultura, respetuoso, podía conversar de cualquier tema, sabía leer correctamente y con gallardía llevaba su traje de paño del campesino acomodado" (Ramírez 1927:99; Díaz 2009).

Estos reportes con violentas expresiones, son elementos de la visión nacionalista y etnocéntrica de los agentes fiscales sobre la población local. En contrapunto, argüía que los carabineros en Codpa entablaban rápidas relaciones sociales, pues "se identifican con los pobladores, estudian sus hábitos y, aunque no olvidan el papel que la nación les ha confiado, van realizando su misión con un tacto admirable", cooperando con "la labor civilizadora y cultural de los capellanes" (Ramírez 1931:126).

La escuela y el ejército, así como los capellanes, profesores y carabineros, formaban parte de la estructura organizativa que el Estado había implementado para administrar los territorios, para obtener el dominio soberano y acceder a la aprobación masiva de la población (Díaz 2006). En dicha estructura, se encontraban los subdelegados rurales, inspectores y jueces distritales. Ramírez concibe a estos agentes como la piedra angular de la chilenización. Decía, que el subdelegado de Tignamar "es todo un patriota; hombre ya cuarentón [que] se ha encerrado en su poblacho y con su colega y amigo, el juez don Fernando Tobar, gobierna su plebe con la misma prudencia, discreción y tino que un mandatario de alto coturno" (Ramírez 1931:44).

En definitiva, concebía a la autoridad, "ya sean los Intendentes o Gobernadores, Subdelegados o Inspectores de Distrito" como aquellos que "han tenido la consigna de mostrar a sus dirigidos cual era la orden que recibían de sus altos jefes, hacer respetar las leyes, amar a la patria y reconocer los derechos de todos los ciudadanos" (Ramírez 1927:192).

\section{Comentarios Finales}

Hemos realizado un abordaje de los múltiples elementos nacionalistas que es posible encontrar en los textos del capellán militar Julio Ramírez Ortizal. Sus anotaciones, entre analogías, violencia simbólica, xenofobia y/o el interés por comprender en parte la cultura andina, se sostienen en un entramado laberinto sociopolítico que fue el complejo proceso de aculturación que experimentaron los aymaras de la sierra ariqueña durante la chilenización (Díaz y Málaga 2013). Como ya insistimos, el capellán veía a los indígenas como un sujeto carente de modernidad o que, en su defecto, se encontraba en vías de ingresar al mundo civilizado representado por la nación chilena.

Consignemos a su vez, que los relatos de Ramírez están en un espacio liminal entre su perspectiva etnocéntrica y cierta sensibilidad etnográfica debido a las lecturas de Joseph de Acosta y otros cronistas. En su textualidad, hay un constante prejuicio añadido a sus descripciones sobre la religiosidad de las comunidades andinas. Ciertamente, esta forma de abordar la narrativa sobre las costumbres indígenas respondía al interés por declarar la integración efectiva de los pobladores andinos a la membresía nacional (Gundermann y González 2009). Hay referencias del proceso de modernización que implícitamente se encuentran en la obra de Ramírez. El misionero construye un relato en el que la "obra civilizadora" ha permitido que los indígenas fueran considerados como chilenos. Aunque, hay resistencia a la implementación de políticas administrativas (Díaz y Ruz 2009; Díaz, et al. 2013) o el reclamo comunitario por la falta de programas de instrucción pública (Díaz y Ruz 2009b).

En un plano analítico, Ramírez nos entrega importantes recursos para la comprensión del proceso de chilenización en las comunidades andinas en dimensiones que escapan a las difundidas por la estructura administrativa secular. Exclamaba "de repente, alguno de los danzantes, mientras se detienen los sones de las zampoñas, lanza a todo pulmón un sonoro ¡Viva Chile!, con repiquete. Es ya el sello inconfundible de chilenidad" (Ramírez 1931:171).

Dicho esto, sus acercamientos al quehacer etnográfico, influyó al parecer, para examinar in extenso prácticas, costumbres y creencias de la religiosidad andina, constituyendo un reflejo de las relaciones y alteridades entre capellanes y comuneros en un territorio fronterizo de permanentes cambios sociopolíticos e identitarios. En efecto, en las observaciones de Ramírez habitan dos polos que pugnan y colisionan. Por un lado, se presenta una comunidad que activa repertorios culturales asociados a los ritos y al ceremonial indígena. Por el otro, a un sacerdote preocupado por "extirpar los errores y 
supersticiones". En este tenso escenario, surgen las referencias detalladas del clérigo, reeditando el ejercicio cronístico sobre la puesta en escena de tradiciones distintas para sus códigos culturales o, como correlato, para plasmar la excentricidad del ceremonial andino.

Los materiales legados por Julio Ramírez son un valioso expediente de la religiosidad andina de inicios del siglo XX, en la cual interactúan agentes y capellanes castrenses con indígenas, con creencias y costumbres diferenciadas que, en definitiva, se articulan en relaciones complejas en las tierras andinas fronterizas.

Agradecimientos: Este artículo es resultado de los proyectos FONDECYT N ${ }^{\circ} 1181844$ y UTA Mayor 5767-18. A su vez, agradecemos a los evaluadores por sus sugerencias y comentarios.

\section{Referencias Citadas}

Acosta, J. 1590. Historia Natural y Moral de Las Indias. Juan de León, Sevilla.

Anderson, B. 1993. Comunidades Imaginadas. Reflexiones sobre el Origen y Difusión del Nacionalismo. Fondo de Cultura Económica, México, DF.

Araneda, F. 1970. Manuel Antonio Roman, 1858-1920. Boletín de la Academia Chilena correspondiente de la Real Española 29:5-162.

Bourdieu, P. 1986. La Escuela como Fuerza Conservadora: Desigualdades Escolares y Culturales. Ediciones El Caballito, México, DF.

Chacama, J. y A. Díaz 2011. Cañutos y soplidos. Tiempo y cultura en las zampoñas de las sociedades precolombinas de Arica. Revista Musical Chilena 216:34-57.

Choque, C. 2013. Violencia, chilenización y los curas peruanos en Arica a inicios del siglo XX. En Tiempos Violentos. Fragmentos de Historia Social en Arica, editado por A. Díaz, R. Ruz y L. Galdames, pp. 149-160. Ediciones Universidad de Tarapacá, Arica.

Choque, C. y A. Díaz 2017. ¡Ahora sí que es Pachallampe! Simbolismo, tecnología y memoria en la siembra de papa en Socoroma, Norte de Chile. Chungara Revista de Antropología Chilena 49 (3):411-426.

Déloye, Y. 2004. Sociología Histórica de lo Político. Lom Ediciones, Santiago.

Díaz, A. 2006. Aymaras, peruanos y chilenos en los andes ariqueños: resistencia y conflicto frente a la chilenización del norte de Chile. AIBR. Revista de Antropología Iberoamericana 1:296-310.

Díaz, A. 2009. Los Andes de bronce. Conscripción militar de comuneros andinos y el surgimiento de las bandas de bronces en el Norte de Chile. Historia 42:371-399.

Díaz, A., L. Galdames y W. Muñoz 2012. Santos patronos en Los Andes. Imagen, símbolo y ritual en las fiestas religiosas del mundo andino colonial (siglos XVI-XVIII). Alpha 35:23-39.

Díaz, A., L. Galdames y R. Ruz 2010. Nación e identidad en Los Andes. Indígenas de Arica y Estado Chileno (1883-1929). Ediciones Universidad de Tarapacá, Arica.

Díaz, A., L. Galdames y R. Ruz 2013. En los Intersticios de la chilenidad: Antonio Mollo y las identidades en conflicto en Los Andes. Putre, 1900-1926. Chungara Revista de Antropología Chilena 45 (3):473-492.
Díaz, A. y P. Lanas 2015. Danzas y devoción en el desierto: Obreros e indígenas en la fiesta de la Virgen del Carmen de La Tirana, Norte de Chile (siglo XX). Latin American Music Review $36: 145-169$

Díaz, A. y A. Málaga 2013. Fiestas religiosas e identidades nacionales: la peruanidad ritualizada en el desierto chileno (siglo XX). En Las Historias que Nos Unen. Episodios Positivos en las Relaciones Peruano-Chilenas, Siglos XIX y XX, editado por S. González y D. Parodi, pp. 469-482. Ril Editores-Universidad de Tarapacá, Santiago.

Díaz, A., P. Martínez y C. Ponce 2014. Cofradías de Arica y Tarapacá en los siglos XVIII y XIX. Indígenas andinos, sistema de cargos religiosos y festividades. Revista de Indias LXXIV: 101-128.

Díaz, A. y R. Ruz 2009a. Comuneros andinos en la administración chilena (Arica, 1880-1929). Revista de Historia Social y de las Mentalidades 13 (2).

Díaz, A. y R. Ruz 2009b. Estado, escuela chilena y población andina en la ex Subdelegación de Putre. Acciones y reacciones durante el período post Guerra del Pacífico (1883-1929). Polis 8:311-340.

Fierro, L. 2010. La atención religiosa católica en las Fuerzas Armadas chilenas. Revismar 2:162-170.

Figueroa, V. 1931. Diccionario Histórico, Biográfico y Bibliográfico de Chile. Imprenta y Litografía "La Ilustración”, Santiago.

Galdames, L. y A. Díaz 2007. La construcción de la identidad ariqueño-chilena durante las primeras décadas del siglo XX. Diálogo Andino 29:19-28.

González, S. 2004. El Dios Cautivo: Las Ligas Patrióticas en la Chilenización Compulsiva de Tarapacá (1910-1922). LOM Editores, Santiago.

Guber, R. 2001. La Etnografía. Método, Campo y Reflexividad. Grupo Editorial Norma, Bogotá.

Gundermann, H. y H. González 2009. Sociedades indígenas y conocimiento antropológico. Aymaras y atacameños de los siglos XIX y XX. Chungara Revista de Antropología Chilena 41 (1):113-164.

Mattei, F. y C. Casalini 2015. La educación del indio. Los jesuitas José de Acosta y Blas Valera sobre la lengua y la capacidad de los nativos peruanos. Nueva Crónica 5:67-91.

Otero, G. 1939. Notas sobre Emeterio Villamil de Rada. En La lengua de Adán y el hombre de Tiaguanaco, editado por E. Villamil, pp. 1-34. Biblioteca Boliviana, La Paz. 
Palacios, R. 1974. La Chilenización de Tacna y Arica. Editorial Arica, Lima.

Pérez, M. 2008. Etnografía y Descripción. El Discurso Etnográfico en la Historia General de las Cosas de la Nueva España de Fray Bernardino de Sahagún. Universidad Pedagógica Nacional, México DF.

Pratt, M. 2010. Ojos Imperiales. Literatura de Viajes y Transculturación. Fondo de Cultura Económica, México DF.

Precht, J. 2005. El obispado castrense de Chile ante el derecho internacional. Política y Estrategia 99:91-103.

Ramírez, J. 1920. El Rancho: Novela de Costumbres Chilenas. s./e., Santiago.

Ramírez, J. 1923. Del Mar y de la Sierra. Imprenta San José, Santiago.

Ramírez, J. 1927. Por la Pampa Adusta. Imprenta de San José, Santiago.

Ramírez, J. 1930a. Voces de la Patria. Imprenta Recurba, Santiago.

Ramírez, J. 1930b. El Imperio Comunista. s./e., Santiago.
Ramírez, J. 1931. Tierras Grises. Imprenta La Tracción, Santiago.

Ramírez, J. 1935. Navegando a Rapa-Nui. Imprenta San Francisco, Santiago.

Ramírez, J. 1937. Historia de Chile. Imprenta Nascimiento, Santiago.

Ramírez, J. 1950. La Virgen del Carmen y Chile. Editorial Difusión, Santiago.

Ruz, R., A. Díaz y R. Fuentes 2011. Timalchaca. Fiesta, Tradición y Costumbre en el Santuario de la Virgen de los Remedios. Corporación Nacional de Desarrollo Indígena, Comisión Asesora Región de Arica y Parinacota del Consejo de Monumentos Nacionales, Arica.

Solodkow, D. 2010. Una etnografía en tensión: "Barbarie" y evangelización en la obra de José de Acosta. Nuevo Mundo Mundos Nuevos. http://nuevomundo.revuues.org/59113 (14 noviembre 2017).

\section{Archivos y Periódicos}

Archivo Histórico "Vicente Dagnino", Universidad de Tarapacá.

El Ferrocarril, Arica.

La Aurora, Arica.

\section{Notas}

${ }^{1}$ De acuerdo con los registros del Departamento Histórico, Cultural y de Extensión del Ejército (en adelante DCHEE), nació el 19 de febrero de 1889; aunque, el registro de nacimiento de la Circunscripción de Santiago fija dicho evento en 1887. Archivo del Registro Civil de Santiago, Libro de Nacimientos, 1887, volumen 46, registro 512, página 171

${ }^{2}$ Hoja de Servicios del Capellán $1^{\circ}$ Julio Ramírez Ortiz. DCHEE.

${ }^{3}$ Hoja de Servicios del Capellán $1^{\circ}$ Julio Ramírez Ortiz. DCHEE.

${ }^{4} \mathrm{Al}$ respecto, véase el discurso pronunciado el 7 de junio de 1922. Periódico El Ferrocarril, Arica, 8 de junio de 1922. Además, le correspondió ayudar al capellán Benjamín Flores, en la bendición de las obras de construcción de la Población Obrera. El Ferrocarril, 24 de septiembre de 1922

5 En 1914 redactó en los "días de mayor actividad" de la Revista Católica (Araneda 1970:80), destacando tanto "en el orden dogmático como en el terreno de las letras profanas", desarrollando ampliamente el cuento y novelismo (Figueroa 1931:601). Del mismo modo, en sus tempranos escritos se interesó por la recopilación de las costumbres y el folklore del valle central chileno. Para 1920 publica " $E l$ Rancho; novela de costumbres chilenas" (Ramírez 1920), donde el protagonista "es un campesino que, conquistado por un agitador, va a la ciudad en busca de bienestar y, al fin, encuentra allí su ruina" (Figueroa 1931:601). Tres años más tarde edita "Del Mar y de la Sierra" (Ramírez 1923), compilando una serie de cuentos y narraciones que "también pregonizaban el nativismo" (Figueroa 1931:601). En la misma línea publicaría "Navegando a Rapa-Nui" (Ramírez 1935), un texto con apuntes y descripciones sobre Isla de Pascua, realizadas durante el viaje de la corbeta "General Baquedano" en 1934. A su vez, dedicó tiempo para obras de corte patriótico, destinadas mayormente a soldados y suboficiales del Ejército. En este ámbito, destacan Voces de la Patria (Ramírez 1930a), Historia de Chile (1937), El Imperio Comunista (1930b) y La Virgen del Carmen y Chile (1950), entre otros.

${ }^{6}$ Por ejemplo, el 14 de abril de 1920, el Ministerio de Relaciones Exteriores aceptó la renuncia del presbítero Agustín Dierich del puesto de profesor de Religión del Liceo de Niñas de Tacna y decretó que su homólogo, Félix A. Díaz, asumiese en su reemplazo. Archivo Histórico "Vicente Dagnino", Intendencia de Tacna, vol. 63, f. 52 (en adelante AHVD).

7 AHVD, Oficios Varios, 1920, vol. 63, f. 56.

${ }^{8}$ AHVD, Notas de la Intendencia, 1922, vol. 134, s.f.

${ }^{9}$ AHVD, Notas de la Intendencia, 1922, vol. 134, s.f.

${ }^{10}$ La Aurora, 7 de octubre de 1922.

${ }^{11}$ La Aurora, 7 de octubre de 1922.

${ }^{12}$ La Aurora, 31 de octubre de 1922.

${ }^{13}$ El Ferrocarril, 18 de diciembre de 1922. De igual manera, las tareas catequéticas no se limitaban al espacio litúrgico o festivo. Ramírez fue nombrado profesor de religión del Instituto Comercial de Arica en 1925, ocupando el cargo hasta 1927. A su vez, fue capellán de la cárcel de Arica, fundando "con el dinero de una colecta pública" los talleres de "zapatería, carpintería y tornería, donde trabajan los presos y aprenden un oficio" (Figueroa 1931:601).

${ }^{14}$ Periódico La Aurora, Arica, 27 de mayo de 1923.

${ }^{15}$ Cuestiones Plebiscitarias. Talleres de "El Pacífico", Tacna, 1926, p. 49.

${ }^{16}$ Entre sus lecturas, estaban los trabajos de Emeterio Villamil de Rada, uno de los pioneros en la etnografía y lingüística aymara de Bolivia durante el siglo XIX (Otero 1939).

${ }^{17}$ AHVD, Oficios Varios, 1927, vol. 80, f. 183. 